Popovic D., Schauerte T., and Johansson J. (2017). "Prefabrication of Single-family Timber Houses Problem Areas and Wastes" In: LC3 2017 Volume II - Proceedings of the 25th Annual Conference of the International Group for Lean Construction (IGLC), Walsh, K., Sacks, R., Brilakis, I. (eds.), Heraklion, Greece, pp. 837-844. DOI: https://doi.org/10.24928/2017/0133

\title{
PREFABRICATION OF SINGLE-FAMILY TIMBER HOUSES - PROBLEM AREAS AND WASTES
}

\author{
Djordje Popovic $^{1}$, Tobias Schauerte ${ }^{2}$, and Jimmy Johansson ${ }^{3}$
}

\begin{abstract}
Industrialization of house building has shifted the activities traditionally done at building site to the off-site assembly. The design, manufacturing processes and on-site assembly in industrialized house building are defined and documented to form a process platform, but these must be evaluated and improved to constantly develop better and more efficient practice. Lean production and philosophy are still not well understood concepts at the shop floor and wasteful activities that decrease production efficiency are often overseen. Current waste categorizations and descriptions seem not to be addressing problem areas and occurrence of waste in prefabrication of single family timber houses. The research aim is to define problem areas that occur during the prefabrication of wall modules, associate them to eight types of waste and identify key problem areas for possible development and improvement. The study was based on secondary data from five case studies that primarily focused on identifying and proposing possibilities for development of productivity. Four problem areas were identified and the future improvement efforts for the prefabrication of single family houses can be placed on developing the processes of the assembly system problem area. The possible future study can aim at quantifying these problem areas.
\end{abstract}

Keywords: Waste categorization, off-site production, wall modules.

\section{INTRODUCTION}

Industrialization of house building is a process that shifts the activities traditionally done at building site to the off-site production (Lidelöw et al 2015). Off-site production has been claimed by various authors to increase the quality of buildings, decrease costs, and increase the efficiency and control of processes (e.g., Apleberger et al 2007). The design, off-site production, and on-site assembly in industrialized house building are defined and documented to form a process platform (Lessing 2015), but these must be evaluated and improved to constantly develop better and more efficient practice. To set the foundation for improvements, the identification of the current state of value adding and non-value adding activities has shown to be a good starting point (Rother and Shook 2003).

Prior work related to waste in off-site production of industrialized house building is already present in the literature (e.g., Sandberg and Bildsten 2011; Barker and Naim 2004). The need to categorize waste in construction industry has already been identified and some contributions are made. Johnsson and Meiling (2009) have compared traditional and industrialized construction in terms of waste of defects. Josephson and Saukkoriipi (2005) have classified waste that occurs in the construction industry supply chain into four

\footnotetext{
PhD Student, Department of Industrial engineering and management, Jönköping University, Jönköping, Sweden, djordje.popovic@ju.se

2 Senior Lecturer, Department of Mechanical Engineering, Linnaeus University, Växjö, Sweden, tobias.schauerte@lnu.se

3 Associate Professor, Department of Forestry and Wood Technology, Linnaeus University, Växjö, Sweden, jimmy.johansson@lnu.se
} 
categories: defects and controls, utilization of resources, health and safety, and system and structure. Gustafsson et al (2012) have followed the same categorization in a single case study and investigated waste that occurs during final on-site assembly of multi-storey buildings with timber structure. However, none of the abovementioned waste categorisations and descriptions seem to address problem areas and occurrence of waste in prefabrication of single family timber houses. Therefore, the research aim is to define problem areas that occur during the prefabrication of wall modules, associate them to eight types of waste and identify the key problem area for possible development and improvement. Off-site production is hereafter referred to as prefabrication.

\section{LEAN PRODUCTION AND DIFFERENT KINDS OF WASTE}

Lean has its origin from the Toyota Production System, aiming at utilizing a company's resources in the most efficient way possible, while delivering a product of the right quality, that customer needs and is willing to pay for. Lean production thus focusses on producing e.g. a product by optimizing resources in a smart manner (Olhager 2013). Two major parts of the Lean production concept are value and waste (Pavnaskar et al 2003). Value is what the customer is willing to pay for (Olhager 2013), whilst waste is considered being all activities that do not create value. Aiming at shortening the lead time from order to delivery, the optimization of resources according to Lean production can be accomplished by eliminating as much waste in production as possible (Liker et al 2009). Ohno (1988), a former Toyota executive, formulated seven different types of waste and Womack and Jones (2010) added another one, as described below. These are the wastes of:

1. Overproduction: by producing more than ordered, the production acts according to push principles instead of pull. Unnecessary costs for inventory and transportation occur. Overproduction is often considered as the worst type of waste, since it causes other wastes (Segerstedt 2008).

2. Waiting: as production stands still, no value is created. According to Lumsden (2006), certain products wait up to $90 \%$ of their time through production.

3. Conveyance: transportation of work-in-process to intermediate storage or between production stages does not add any value to the product (Liker et al 2009). It is impossible to eliminate but should be reduced as much as possible.

4. Over-processing: refining products more than necessary, i.e. as demanded by the customer (Lumsden 2006), but as well ineffective refining due to bad choice of tools and/or machinery or bad product design (Liker et al 2009). Therefore, in this study this type of waste will be referred to as inappropriate processing (Bicheno and Holweg 2008).

5. Excess inventory: too many work-in-process articles and storages can cause e.g. longer lead times, damaged products, or transportation delays. Yet, it could even hide problems related to production planning (Segerstedt 2008).

6. Unnecessary motions: it is related to both human and layout factors. The operations have to be performed in an ergonomic way in an optimal layout. (Bicheno and Holweg 2008). Basically, all kind of transportation is waste as it never creates value but only prolongs lead times (Liker et al 2009).

7. Defects: producing products that cause adjustments, reparations, need to be reworked in any way or even scrapped and replaced (Liker et al 2009). 
8. Unused employee creativity or expertise: managers not listening to their employees will lose time, ideas, competence, improvements and miss chances to learn (Womack and Jones 2010).

As value stream mapping identifies all activities in order to produce the final product, the above-mentioned types of waste will be part of that (Schauerte et al 2015). According to the Toyota Production System, all types of waste should be eliminated, or at least reduced as much as possible, to improve production efficiency (Liker 2004).

\section{CASE COMPANIES}

In this study, five companies have been investigated. These are referred to as cases a, b, c, $\mathrm{d}$, and e. All of them act on the same market, are direct competitors producing wooden single family-houses and are located in the province of Småland in Southern Sweden. The industry at hand is highly competitive, as e.g. described by Schauerte et al (2014) and Schauerte and Lindblad (2015). As the authors of this study and the involved universities are cooperating with the case companies in various research projects, they will be handled as anonymous entities in this study. Elsewise, potential sensitive results could be used to create competitive advantage, which might burden the existing relationship between the authors and the companies.

\section{METHOD}

This study is based on secondary data from five case studies conducted during 2014-2016 (Andersson and Jönsson 2016; Tingström and Gunnarsson 2014; Björk and Andersson 2016; Ulriksson et al 2014; Popovic et al 2016). The aim of those studies was to identify and propose possibilities for productivity development in the pre-fabrication of wall modules, i.e., offsite production. The basic tool used as a starting point for all the studies was value stream mapping and data collection was based on observations of the production process for identification and mapping of that process. This was followed up by time studies of the different process steps and shorter interviews or discussions with operative staff, mostly during continuous observations of the production. Semi-structured interviews with production management staff were conducted to collect information about critical aspects in the production.

The data used in this study is of qualitative manner and collected from the material and the reports from the five case studies described above, with the specific aim of identifying problem areas and connecting them with waste that has occurred. The data was analysed using workshop technique (Williamson 2002). The participants of the workshop were four academic researchers and two middle managers from one of the case companies. The first goal of the workshop was to discuss and make a consensus on which types of wastes that are related to each observation. The second goal of the workshop was to categorize observations into problem areas to enable easier representation of findings.

\section{FINDINGS AND DISCUSSION}

As the primary data was collected with different research questions, the observations made in the case studies were described as problem instances in a qualitative manner. Some observations are common between the case studies but the majority is different or at best similar due to the uniqueness of production systems. 
To fulfil the aim of this study, the authors have first categorized problem observations into four problem areas: material handling, internal logistics, assembly system, and work balancing. In the following section, the categorization of observations will be given together with the occurrence in case companies in parenthesis. The grouping of instances into problem areas and case companies is shown in Table 1. The authors define the problem areas as following:

- Material handling refers to the activities of moving materials, subassemblies, and tools from their storage to the point of assembly. Operators must walk long distances to fetch materials, components and/or subassemblies (all cases). A structure or replenishment of intermediate storage is not defined (a, b, and c). Here are also included issues of non-ergonomic activities that the operators perform during material handling (a). Working environment: issues caused due to the lack of systems that effectively collect dust and material and tool residuals.

- Internal logistics is related to the material flow between different process groups within the factory. Problem instances can be related to: available capacity of resources - trucks ( $\mathrm{a}$ and $\mathrm{b})$ planning of work orders for trucks (a and $\mathrm{c})$, truck routes - factory layout (a, c, and e).

- Assembly system refers to problem instances that occur in, or are related to, assembly processes, equipment, control, and operators. Physical and cognitive levels of automation in the assembly processes are relatively low and non-optimal, although the design process is performed using ICT tools that can provide $\mathrm{CAD} / \mathrm{CAM}$ data to the production ( $\mathrm{a}, \mathrm{d}$, and e). Another problem instance relates to the usage of paper based drawings in the production, while there are already available digital information making prerequisite for a shift towards digital information carriers (Popovic and Winroth 2016) (a, d, and e). Some operations of the assembly process are non-ergonomic ( $\mathrm{d}$ and e). Idle times of the assembly line are observed (c and d). Parallel support processes, that supply the assembly line with parts and components, produce more than needed (c), have long setup time (e), could be part of the assembly process instead (b and c) and have illogical positioning of machines ( $\mathrm{b}$ and $\mathrm{c})$. There is a lack of preventive maintenance (a and d) of machine resources. The assembly lines lack flexibility for special variants. This leads to double work on some parts, since there is no other way to realize certain design with an available assembly process (b, c, d, and e).

- In this paper, work balancing is referred to as unevenly distributed operations and tasks in assembly lines for wall modules (all cases) or unbalanced productivity between all departments to form a whole product (house), causing bottlenecks (a and d) and thus having unnecessary work-in-progress. Companies are either producing parts in batches for the intermediate storage or are ordering materials or subassemblies from suppliers in batches. 
Djordje Popovic, Tobias Schauerte and Jimmy Johansson

Table 1: Overview of the problem areas and their presence in the case companies in terms of number of problem observations.

\begin{tabular}{cccccc}
\hline Problem area & Case a & Case b & Case c & Case d & Case e \\
\hline Material handling & 4 & 2 & 2 & 1 & 1 \\
Internal logistics & 4 & 1 & 2 & 0 & 1 \\
Assembly system & 3 & 3 & 5 & 6 & 5 \\
Work balancing & 2 & 1 & 1 & 4 & 1 \\
\hline
\end{tabular}

After the problem areas have been defined, the next goal of the workshop was to associate them to eight types of wastes. Problem observations on the other hand rarely related to only one type of waste. To give an overview and facilitate discussion, the occurrence in case studies was summed both per problem area and per type of waste (Table 2).

Table 2: Connection between problem areas and eight types of waste in case companies. Superscript is used to denote the number of waste observations per problem area if it is higher than one in a particular case.

\begin{tabular}{|c|c|c|c|c|c|c|c|c|c|}
\hline & $\begin{array}{l}\text { Over } \\
\text { prod. }\end{array}$ & Wait. & Trans. & $\begin{array}{c}\text { Inapp. } \\
\text { proc. }\end{array}$ & $\begin{array}{l}\text { Unn. } \\
\text { inv. }\end{array}$ & $\begin{array}{l}\text { Unn. } \\
\text { mot. }\end{array}$ & Def. & $\begin{array}{l}\text { Unus. } \\
\text { h. p. }\end{array}$ & $\Sigma$ \\
\hline $\begin{array}{l}\text { Material } \\
\text { handling }\end{array}$ & & & $\begin{array}{c}\mathrm{a}^{3}, \mathrm{~b}, \\
\mathrm{c}^{2}, \mathrm{~d}, \mathrm{e}\end{array}$ & $\mathrm{a}$ & $a^{2}, b, c$ & $\begin{array}{c}a^{3}, b, \\
c^{2}, d, e\end{array}$ & & b & 22 \\
\hline $\begin{array}{l}\text { Internal } \\
\text { logistics }\end{array}$ & & $\frac{a^{3}, b}{c^{2}}$ & $\mathrm{a}^{2}, \mathrm{c}, \mathrm{e}$ & $\begin{array}{c}\mathrm{a}, \mathrm{b}, \mathrm{c} \\
\mathrm{e}\end{array}$ & $a^{2}$ & $\mathrm{c}, \mathrm{e}$ & & & 18 \\
\hline $\begin{array}{l}\text { Assembly } \\
\text { system }\end{array}$ & & $\begin{array}{c}\mathrm{a}, \mathrm{c}^{2}, \\
\mathrm{~d}^{2}\end{array}$ & $\mathrm{~b}, \mathrm{c}$ & $\begin{array}{c}a^{3}, b^{3} \\
c^{5}, d^{6} \\
e^{5}\end{array}$ & $\mathrm{c}$ & $b, c, d$ & $d$ & $\mathrm{~b}, \mathrm{c}$ & 36 \\
\hline $\begin{array}{c}\text { Work } \\
\text { balancing }\end{array}$ & & $\begin{array}{l}\mathrm{b}, \mathrm{c}, \\
\mathrm{d}^{3}, \mathrm{e}\end{array}$ & & $a, d^{3}$, & $\mathrm{a}$ & $\mathrm{a}, \mathrm{e}$ & & & 13 \\
\hline$\Sigma$ & 0 & 17 & 14 & 31 & 8 & 15 & 1 & 3 & \\
\hline
\end{tabular}

By interpreting the numbers of waste observations in Table 2, it is possible to differentiate between types of waste and problem areas in terms of their significance for improvement. This is based solely on the assumption that eliminating waste can contribute to an improved resource efficiency (Liker et al 2009). Below, the types of waste, in terms of their significance, are shortly discussed in a descending order:

- The waste of inappropriate processing is present in the assembly system areas of all case companies and is, by the number of observations, the most significant waste identified. It points out that processes of assembly, parallel support and assembly control should be changed or improved. As it can be seen from the table above, processes of internal logistics and work balancing can be done differently to improve the prefabrication efficiency. 
- The wastes of waiting, transporting, and unnecessary motions are the second significant group of wastes, present in almost all case companies and problem areas. With currently used resources, in all four problem areas, these three types of wastes are present in almost all case companies. The waste of waiting is mainly related to work balancing, while the waste of transporting and unnecessary motions is mainly related to the area of material handling.

- The waste of unnecessary inventory is less present, while the waste of overproduction has not been identified. This might be explained due to the fact that all companies operate by orders and the final products are always produced in right amounts.

- The wastes of defects and unused human potential were two less significant types of wastes. This can be dependent on how the primary data was collected and the research questions that were used. Since neither quality control nor human resources were the primary focus in the five case studies, the result in this study can be biased and not show the real significance of these two types of wastes. However, the waste of defects in prefabrication processes was comprehensively covered in the study of (Johnsson and Meiling 2009).

An interesting example of wastes that occur concurrently is identified in the problem area material handling. Since material handling is performed manually in most of the cases, the operators walk certain distances every time to fetch material from the intermediate storage, which is a repetitive waste of unnecessary motions. At the same time the trucks are used to replenish materials in the intermediate storage. Therefore, the waste of transporting is present. Hypothetically, having systems for automatic material handling instead of manual would eliminate these two types of waste or at least decrease their impact.

Of all the problem areas, assembly systems are related to the highest number of waste observations, counting all types of wastes in all the cases. That can be an indicator of a primary problem area of wall module assembly. The second significant problem area is material handling, followed by internal logistics and work balancing. This finding can contribute to facilitated prioritization during the process platform development (Lessing 2015).

What is important to notice is that both different types of wastes and problem areas are interrelated. The change/improvement made in one problem area can cause both positive or negative changes in other areas. Likewise, eliminating one type of waste can affect elimination as well generation of another type of waste. Therefore, in order to optimize and improve certain parts of the prefabrication process, a holistic view is needed (Barker and Naim 2004). The examples of related types of wastes are overproduction and unnecessary inventory and waste of transporting and unnecessary movements (Liker et al 2009). Depending on the work organisation, some operations done within the assembly process are, in other organisations, included in the parallel support processes for assembly. To describe the interrelations between assembly systems and work balancing problem areas with related wastes, an example is given: shifting an operation, that is the part of an assembly sequence, to be a parallel support for the assembly instead, can possibly reduce the wastes of waiting and unnecessary motions, while it can generate the waste of transporting, depending on the new physical location for this operation. 


\section{CONCLUSIONS}

Following the aim of this study, four problem areas of wall module assembly were defined: material handling, internal logistics, assembly system, and work balancing. Although qualitative data was used, the findings to certain extent point out to what extent which wastes are present in the four problem areas. This, by relating to the number of waste observations that were made during the workshop. Considering observations from all case companies, the waste of inappropriate processing was the most significant one, notably in the assembly systems problem area. The wastes of waiting, transport and unnecessary motions were the second most significant ones. Furthermore, the problem area of assembly systems had the highest total number of waste observations. Therefore, the main conclusion is that future improvement efforts for the prefabrication of single family houses can be placed on developing the processes of the assembly system problem area.

Apart from the elimination of several types of wastes, improving one problem area can lead to changes in other problem areas as they are interrelated. Hence, a holistic approach should be used for the sake of avoiding sub-optimization. Therefore, the findings of this study can be a starting point for future work that aims at quantifying these problem areas.

\section{ACKNOWLEDGEMENTS}

This research project is part of the graduate school ProWOOD which is a collaboration between School of Engineering at Jönköping University, Linnaeus University, Nässjö Träcentrum, several companies, and two research institutes. The graduate school is financially supported by The Knowledge Foundation (KK-stiftelsen). The authors would also like to thank Andersson A. and M., Björk S., Gunnarsson A., Jönsson F., Mustafic M., Rydell J., Tingström A. and Ulriksson J. for gathering the original data used in the current study.

\section{REFERENCES}

Andersson, A. \& Jönsson, F. 2016. Effektivisering av produktion på producerande företag.: Fallstudie på Eksjöhus AB.

Apleberger, L., Jonsson, R. \& Åhman, P. 2007. Byggandets industrialisering nulägesbeskrivning.

Barker, R. \& Naim, M. M. 2004. Housebuilding supply chains: remove waste-improve value. The International Journal of Logistics Management, 15, 51-64.

Bicheno, J. \& Holweg, M. 2008. The Lean toolbox: The essential guide to Lean transformation, Picsie Books.

Björk, S. \& Andersson, M. 2016. Effektivisering av industriell tillverkning: En fallstudie på Eksjöhus AB.

Gustafsson, A., Vessby, J. \& Rask, L.-O. 2012. Identification of potential improvement areas in industrial housing: A case study of waste. Lean Construction Journal, 6177.

Johnsson, H. \& Meiling, J. H. 2009. Defects in offsite construction: timber module prefabrication. Construction Management and Economics, 27, 667-681.

Josephson, P.-E. \& Saukkoriipi, L. 2005. Slöseri i byggprojekt: behov av förändrat synsätt. External organization.

Lessing, J. 2015. Industrialised House-Building-Conceptual orientation and strategic perspectives. Lund University. 
Lidelöw, H., Stehn, L., Lessing, J. \& Engström, D. 2015. Industriellt husbyggande, Studentlitteratur.

Liker, J. K. 2004. The toyota way, Esensi.

Liker, J. K., Erkelius, L. \& Hallberg, J. 2009. The Toyota way: lean för världsklass, Liber.

Lumsden, K. 2006. Logistikens grunder: teknisk logistik, Studentlitteratur.

Ohno, T. 1988. Toyota production system: beyond large-scale production, crc Press.

Olhager, J. 2013. Produktionsekonomi: principer och metoder för utformning, styrning och utveckling av industriell produktion, Studentlitteratur.

Pavnaskar, S., Gershenson, J. \& Jambekar, A. 2003. Classification scheme for lean manufacturing tools. International Journal of Production Research, 41, 3075-3090.

Popovic, D., Fast-Berglund, Å. \& Winroth, M. Production of customized and standardized single family timber houses-A comparative study on levels of automation. 7th Swedish Production Symposium, 2016.

Popovic, D. \& Winroth, M. Industrial timber house building-levels of automation. ISARC. Proceedings of the International Symposium on Automation and Robotics in Construction, 2016. Vilnius Gediminas Technical University, Department of Construction Economics \& Property, 1.

Rother, M. \& Shook, J. 2003. Learning to see: value stream mapping to add value and eliminate muda, Lean Enterprise Institute.

Sandberg, E. \& Bildsten, L. 2011. Coordination and waste in industrialised housing. Construction Innovation, 11, 77-91.

Schauerte, T. \& Lindblad, F. Productivity Trend in the Off-Site Construction Sector of Wooden Houses. Pro Ligno, 2015. 432-439.

Schauerte, T., Lindblad, F. \& Johansson, J. Industry structure and risk positions for wooden single-family house firms in Sweden: evaluating their potential to enter the multifamily house segment. Forest Products Society International Convention, Québec City, Canada, August 10-14, 2014, 2014.

Schauerte, T., Svensson, V. \& Allhorn, S. Improving Production Efficiency to Increase the Capacity and Profitability of a Swedish Wooden Single-Family House Producer. 58th International Convention of Society of Wood Science and Technology, June 7-12, 2015, Jackson, 2015. Society of Wood Science and Technology (SWST), 775783.

Segerstedt, A. 2008. Logistik med fokus på material-och produktionsstyrning, College of Liberal Arts and Sciences.

Tingström, B. \& Gunnarsson, A. 2014. Möjliggörande av högreproduktionstakt vid tillverkning av kundanpassade ytterväggselement.

Ulriksson, J., Mustafic, M. \& Rydell, J. 2014. Effektivisering av intern resurshantering på ett tillverkande trähusföretag: En fallstudie utförd på Smålandsvillan.

Williamson, K. 2002. Research methods for students, academics and professionals: Information management and systems, Elsevier.

Womack, J. P. \& Jones, D. T. 2010. Lean thinking: banish waste and create wealth in your corporation, Simon and Schuster. 